\title{
INTEGRATED DISEASE MANAGEMENT TO ERADICATE NEW ASPARAGUS DISEASES POSING BIOSECURITY THREAT TO NEW ZEALAND
}

\author{
L-H. CHEAH ${ }^{1}$, C.M. HORLOCK ${ }^{2}$ and D.R. BEASLEY ${ }^{2}$ \\ ${ }^{1}$ Crop \& Food Research, Private Bag 11600, Palmerston North, New Zealand \\ ${ }^{2}$ DPI\&F, Applethorpe Research Station, Stanthorpe Qld 4380, Australia \\ Corresponding author: cheahl@crop.cri.nz
}

Collaborative research between the Queensland Department of Primary Industry and Fisheries and Crop \& Food Research has investigated field-applied fungicides and postharvest treatments for the management of asparagus rust (caused by Puccinia asparagi) and phomopsis stem blight (caused by Phomopsis asparagi) of asparagus in Queensland. Field trials were carried in grower's properties at Mundubbera (trial 1) and Warwick (trial 2), Queensland. Fungicides were applied to asparagus fern approximately 4 weeks after spear emergence and then again at 8 weeks after emergence using a petroldriven spray tank, through an adjustable hollow cone nozzle at a rate of approximately 5 litres/plot. Four weeks after the second fungicide application the percentage of plants with disease symptoms was estimated. In trial 1, the fungicides difenoconazole and propiconazole were shown to reduce the incidence of asparagus rust. Difenoconazole and carbendazim reduced the severity of phomopsis stem blight in trial 2 . In preliminary experiments some postharvest disinfestants (a mixture of chlorine + bromine, chlorine dioxide, peroxyacetic acid, sodium hypochlorite and chlorine) were highly effective at reducing pathogen spore germination in vitro. Integrated strategies based on field management and postharvest disinfection methods are suggested for use should these diseases spread to New Zealand.

\section{FUNGICIDE EVALUATION FOR THE CONTROL OF STRAWBERRY POSTHARVEST ROTS}

\author{
O.E. TIMUDO-TORREVILLA ${ }^{1}$, R.W. CHYNOWETH ${ }^{1}$, W.R. HENSHALL ${ }^{1}$, \\ T. OLSEN ${ }^{1}$, K.S.H. BOYD-WILSON ${ }^{2}$, L. HAWES ${ }^{3}$ and M. WALTER ${ }^{2}$ \\ ${ }^{1}$ HortResearch, Private Bag 92169, Auckland, New Zealand \\ ${ }^{2}$ HortResearch, PO Box 51, Lincoln, New Zealand \\ ${ }^{3}$ Enderley Consultants, 78 Enderley Avenue, Hamilton, New Zealand
}

Corresponding author: Otimudo@hortresearch.co.nz.

Postharvest fruit rots are a serious problem in New Zealand strawberry production. Over the last 2 years, several trials on control of fruit rots were conducted on grower properties in Auckland (3 sites), Hamilton (2 sites) and/or Canterbury (1 site). A total of 13 biological and chemical fungicides were tested. Fungicides (up to 4 applications) were applied at weekly intervals generally during main flowering. Subsequent rots were assessed weekly for five harvests. Ripe, undamaged fruit was incubated at $21 \pm 3^{\circ} \mathrm{C}$ for up to 7 days to allow rots to develop. Early season rots were dominated by grey mould (Botrytis cinerea), whereas late season rots were dominated by leak (Rhizopus spp. and Mucor spp.). In Auckland, although some disease reductions were observed, none of the fungicide treatments consistently reduced postharvest storage rots. By contrast, rots were reduced in Hamilton and Canterbury. Surface sterilisation of green and ripe fruit suggest that strawberry postharvest rots are caused by direct infection of the fruit at or near maturity rather than an expression of latent infections established during flowering. This, in combination with the warm, wet and humid climate in Auckland at harvest, may explain the lack of postharvest disease control by fungicides applied at flowering. 